\title{
Vidas Heterotópicas, Vidas Infames, Vidas Outras: um percurso antropológico no pensamento de Foucault
}

\author{
Heterotopic Lives, Infamous Lives, Other Lives: an anthropological \\ route in the work of Michel Foucault
}

\section{Julia Naidin*}

Universidade Federal do Rio de Janeiro, UFRJ, Rio de Janeiro, RJ, Brasil

\section{Resumo}

Proclamada em As Palavras e as Coisas, a tese foucaultiana de que o sujeito não é evidente recebe diferentes tratamentos nos movimentos do pensamento do filósofo. "O sujeito" sempre foi tratado como um problema e como um lugar de problematização, de diagnóstico da genealogia das forças, em constantes agenciamentos. Foucault pensa a antropologia a partir da crise epistêmica da modernidade para reposicionar os limites e as possibilidades do sujeito moderno em sua relação com seu mundo. Apresenta-se, através de breves existências que emergem e ousam contra o poder, a importância de uma nova imaginação para criar outras formas de vida. O que Foucault nos diz através de vidas intempestivas as extrapola e nos mostra a explicitação de experiências radicais em outros modos de ser. Outros corpos, outros desejos, novas audácias, outros modos de ser e de lutar, via corpo, arte, loucura, pensamento crítico, ação política. Em todas essas formas

\footnotetext{
* JN: Doutora em Filosofia, e-mail: jnaidin@gmail.com
} 
tão diferentes, identificamos um lugar de ruptura em comum. “Estranhos poemas" é como Foucault se refere a experiências de vidas irredutíveis, sobre as quais pretendemos apontar um olhar. Defendemos a ideia de que o tema do trabalho sobre si, entendido como uma demanda pela criação de gestos ativos e transgressores direcionados a dar nova forma e sentido ao próprio modo de ser — a questão da subjetividade na obra de Foucault.

Palavras-chave: Foucault. Heterotopia. Infâmia. Ética.

\section{Abstract}

Officially announced in The order of things, Foucault's thesis that the subject is not evident received different treatments in the philosopher's thought. "The man" was always conceived as a problem and a focus of problematization and diagnostic of the genealogy of forces in constant relation. Foucault thinks anthropology from the epistemic crisis of modernity to reposition the limits and possibilities of the modern subject in his relationship with his world. Foucault shows, trough brief existences that emerge and dare the power, the importance of a new imagination to create other forms of life. What Foucault tells us through them extrapolates and shows the explanation of radical experiments in other ways of being. Other bodies, other desires, new boldness, other ways of being and fighting, via body, art, madness, critical thinking, political action. In all these ways so different, we identify a place of rupture in common. "Strange poems" is how Foucault refers to experiences of irreducible lives on which we intend to appoint a look. We defend the idea that the work of the subject on itself, understood as a demand for creation of transgressors and active gestures in direction to give new shape and meaning to their own way of being - the questions of subjectivity in Foucault's work.

Keywords: Foucault. Heterotopia. Infamy. Ethics.

\section{Introdução}

Partindo da descontinuidade radical do percurso de Foucault, pretendemos demonstrar uma coerência interna em tal percurso, quando considerado do ponto de vista da problematização da questão do 
sujeito na relação estabelecida por ele com as práticas epistêmicas, com as práticas disciplinares e normalizadoras e com as práticas de si.

Esta é parte de uma pesquisa que se faz orientada em torno dos conceitos "heterotopia", "infâmia", "vida-outra" tentando pensar o efeito e a influência de insurgências na vida que, segundo pretendemos analisar, causaram um tipo de revolução epistêmica, ainda que uma microrrevolução. Como sabemos, a filosofia de Foucault opera nas articulações entre saber e poder e, no modo como estas articulações formam sujeitos através dos enlaces políticos, do nível institucional ao nível do desejo. Nesta perspectiva, vidas dissidentes dos regimes normativos que apontam paradoxos ou impossibilidades no choque entre existências e a rede saber-poder emergem como campos férteis a novas produções de sentido, de governo, de cuidados, de tecnologias.

Foucault termina As palavras e as coisas com uma aposta: lança a bela suspeita da figura de um homem apresentado como invenção recente, como imagem desenhada que, poder-se-ia apostar, "desvaneceria, como, na orla do mar, um rosto de areia” (FOUCAULT, 2007). Apesar do fato de tal passagem ter sido associada à polêmica humanista da morte do homem, Foucault, nesse período, estava tecendo uma história da arqueologia dos saberes para reconfigurar a própria ideia moderna de homem, revisitando seu balizamento. Quando o filósofo usa essa imagem, ele se refere, antes, ao terreno arenoso do mar, sobre o qual a imagem do homem se desenha. A crítica se direciona aos espaços e às organizações dos saberes que sustentam a figura moderna de homem. O olhar de Foucault nos sugere uma desorganização desse contorno definido, uma vez que seus traços são variáveis em solos movediços.

Na década de 80, Michel Foucault apresenta o conceito de "vida-outra" referindo-se a um modo de existência que problematiza a moralidade de seu tempo criando um embate político, uma postura ética, um risco na relação com si mesmo e com os outros.

Este trabalho não pretende propor uma unidade, coesão ou linearidade no percurso foucaultiano, tão diverso e inesperado. Ele pretende uma atenção dada a um aspecto de seu modo de trabalho que, em funcionalidades e aparições distintas, recorre à própria vida para 
apresentar uma vida outra. Elas são muitas e possuem sentidos distintos no novelo de trabalho que podemos percorrer: Pièrre Rivière, Herculine Barbin, mais evidentemente, mas outros que aparecem em sua conotação mais ampla: Bataille, Diógenes, Kant. Porém, não se trata tampouco de determo-nos, nestas breves páginas, sobre as especificidades destas figuras no corpus foucaultiano. O que interessa é pensar uma função de diferenciação da vida, através de vidas em modos de ser e exprimir que apresentem outros rostos por serem escritos na areia, fora dos critérios da moralidade epistêmica normativa, que se cria a partir também da ideia de pessoa e seus questionamentos na obra foucaultiana. No espaço plano onde as coisas normalmente se distribuem e se nomeiam, o uso que Foucault faz das vidas que apresentamos traz novas possibilidades de relações entre o sujeito e a verdade de seu tempo, novas possibilidades que se criam e se recriam de maneiras inusitadas, destemidas, inaceitáveis, impossíveis.

O estranhamento, a impossibilidade, o não saber que nosso pensamento experimenta com os desvios orgânico-comportamentais, os quais não se permitem categorizar a partir de propriedades formais, regras supostamente naturais, linearidades comportamentais, são mormente importantes à ideia que pretendemos propor. As análises foucaultianas dos espaços como lugares de visibilidade primordial da articulação do poder sobre os corpos são o que apresenta o solo no qual as desestabilizações arqueológicas que as heterotopias dessas vidas-obras emergem. Tais figuras, aqui tratadas como personagens que Foucault se utiliza como modus filosófico, são seres heterotópicos, pois constituem a criação de significados que não se permitem contornados por lugares, não cabem no campo das práticas disciplinares das normatividades e produções. O discurso não é uma expressão tardia do poder. Ambos são diretamente implicados e constituem-se no próprio acontecimento. Nesse contexto, a função da linguagem e o exercício de uma "contra-história" são a busca de casos que atravessam os discursos, a verdade e os limites que circunscrevem um tempo e seus respectivos modos de vida, na busca por um encontro com uma vivacidade perdida e abafada pelo poder. 


\section{Vidas heterotópicas}

Na década de sessenta, Foucault nos fornece o conceito de heterotopia para criar uma possibilidade de pensamento sobre lugares diferenciados, para falar de um pensamento sobre o espaço que constitui diferenciações em regiões estabelecidas, que contestam tanto a mitologia quanto a realidade dos diferentes tipos de lugar que penetramos. A heterotopia deve, em primeiro lugar, marcar sua distinção da utopia - que se refere justamente ao que não possui lugar nenhum - pois se refere a lugares forçosamente outros. Lugares que na sociedade constituem uma margem, uma ambiguidade, um desvio, e que são reservados a indivíduos ou eventos com existências inapropriadas aos lugares funcionalmente estabelecidos em um corpo social - constituem um movimento desviante em relação a um regulamento.

Quando o autor analisa lugares como casas de repouso, clínicas psiquiátricas, prisões, asilos, ele apresenta a noção de "Heterotopologia" para falar da relação essencial que as sociedades estabelecem com os diferentes tipos e naturezas dos lugares, infinitamente variáveis:

[...] não há provavelmente nenhuma sociedade que não constitua sua heterotopia, ou suas heterotopias [...] talvez não exista, em toda a superfície do mundo ou em toda a história do mundo, uma única forma de heterotopia que tenha permanecido constante (FOUCAULT, 2001a).

A heterotopia possui, como regra geral, a operação de uma justaposição de vários elementos heterogêneos e incompatíveis em um lugar real que os faz combinar, contrariando uma determinada ordem da razão. Esta justaposição emerge como a contestação da ordenação de nossos espaços ordinários. Contestação que pode se manifestar tanto como a criação de um espaço ilusório que denuncia a própria realidade como ilusão quanto, ao contrário, criando um outro espaço real que, de tão meticulosamente aparelhado, desorganiza a disposição dos espaços ordenados e funcionais. 
Foucault abre As Palavras e as coisas com um magnífico prefácio no qual vemos, através de Borges, nossa incapacidade de pensar em relações de espaço impossíveis:

[...] as heterotopias inquietam, sem dúvida porque solapam secretamente a linguagem, porque impedem de nomear isto $e$ aquilo, porque fracionam os nomes comuns ou os emaranham, porque arruínam de antemão a "sintaxe", e não somente aquela que constrói as frases - aquela, menos manifesta, que autoriza "manter juntos" (ao lado e em frente umas das outras) as palavras e as coisas. Eis porque as utopias permitem as fábulas e os discursos: situam-se na linha reta da linguagem, na dimensão fundamental da fábula; as heterotopias [...] dessecam o propósito, estancam as palavras nelas próprias, contestam, desde a raiz, toda possibilidade de gramática; desfazem os mitos e imprimem esterilidade ao lirismo das frases (FOUCAULT, 2007).

No prefácio, Foucault apresenta, com Borges, uma enciclopédia chinesa que distribui os animais em quatorze classes de diferentes tipos. Trata-se, porém, de uma distribuição que desconstrói toda a proposta de organização que nossa mente acostumada espera receber. Surpreendemo-nos com um ordenamento inusitado que apresenta outras ordens possíveis a partir de critérios outros e desconhecidos. A heterotopia se opõe à utopia, entendida como um lugar imaginário criado a partir de uma direção discursiva na construção fictícia de um espaço constituído pela linguagem. Contra tal bom senso, a lista de Borges apresenta uma dobra da linguagem sobre si mesma e uma experiência na qual "a heterotopia arruína não somente a sintaxe das frases, mas também aquela menos manifesta que mantém unidas as palavras e as coisas" (FOUCAULT, 2007). Releiamos o trecho de Borges:

Os animais se dividem em: a) pertencentes ao imperador, b) embalsamados, c) domesticados, d) leitões, e) sereias, f) fabulosos, g) cães em liberdade, h) incluídos na presente classificação, i) que se agitam como loucos, j) inumeráveis, $k$ ) desenhados com um pincel muito fino de pente de camelo, 1) et cetera, m) que acabam de quebrar a bilha, n) que de longe parecem moscas. 
O que está sendo dito, tanto por Borges quanto por Foucault, é que não podemos pensar sem supor um espaço de ordem, sem supor uma zona de mediação como solo de nossa percepção, de nosso discurso e de nosso saber, que garanta a possibilidade de articulação entre o visível e o enunciável. É justamente o "encanto exótico de um outro pensamento" (FOUCAULT, 2007) que nos apresenta o limite do nosso.

Na impossibilidade que se manifesta no texto de Borges, o que se insinua é o limite do próprio pensamento, um limite que somos forçados a experimentar através da literatura e que, conforme avança o livro de Foucault, percebemos análogo a nossa limitação de percebermo-nos como seres circunstanciais e variáveis. Devemos buscar, portanto, através da ideia de heterotopia a apresentação de uma crise com a organização de um determinado tempo, que rompe com a classificação coerente das relações e das ordens contínuas que a linguagem, o olhar e o espaço da funcionalidade pretendem imprimir.

Vejamos bem, a importância da ideia de heterotopia no pensamento de Foucault deve ser compreendida de modo que nos afaste de um lugar comum e simplificador contra o pensamento do autor. Toda a análise dos biopoderes e dos campos disciplinares constitui uma "dupla camada" à metafísica de um poder, um poder abstrato, imaterial, que está, ao mesmo tempo, em toda parte e em lugar algum. Ainda que a abstração, a imaterialidade e a pluralidade de lugares e manifestações que o poder ocupe seja, por definição, múltipla, difusa, inconsistente e imprevisível, existe uma dimensão do poder que é concreta, efetiva, fazendo com que ele seja compreendido através dos espaços concretos nos quais se mostra e atua em sua dispersão, a um só tempo anárquica e estratégica.

Em 14 de maio de 1967, Foucault é convidado para falar a um grupo de estudantes de arquitetura sobre a noção de espaço. Nessa tarde, ele fala das heterotopias como corpos utópicos e ativos: "Uma ciência que teria por objeto espaços diferentes, lugares outros, essas contestações míticas e reais do espaço no qual vivemos." (FOUCAULT, 2001a) criando, assim, heterotopologias. Um pensamento dedicado à criação de espaços que criam visibilidades novas como lugar de alteridade na articulação da "quase-metáfora" do poder, incorporável, 
suposto em toda parte e posto em parte alguma. A história dos poderes é feita como uma história dos espaços através dos quais o poder se mostra e se transforma nas rupturas das tensões que limitam os espaços e configuram lugares fora do tempo, anacrônicos, ligados a passagens, rituais e mutações. Assim se opera o olhar da arqueologia: "como uma heterotopologia da fenomenologia na dispersão anárquica do poder que espacializa as subjetividades pela ideia de lugar" (FOUCAULT, 2009). O lugar da heterotopia emerge como contra-espaço, como região de passagem e como parte do movimento de ruptura do poder, sempre recriado, como jogo em pleno ato. [...] carnavalização da existência ordinária. Eles ritualizam as clivagens, os desvios, lhes localizam (FOUCAULT, 2009).

\section{Vidas infames}

Em janeiro de 1977, na revista Les cahiers du chemin, Foucault publica o texto $A$ vida dos homens infames. A revista se constituiu como um projeto intitulado Les viés parallèles, publicando textos sobre casos de vidas desordenadas, indocilizáveis e obscurecidas. $\mathrm{O}$ que ele registra é justamente a referência a um conjunto cultural que caracteriza uma determinada atualidade que deve ser tratada como objeto de reflexão. Essa "antologia das existências" não pretende entrar em categorias ou classificações, tampouco criar novas. As vidas que Foucault resgata "por acaso" nesse texto não possuem uma ligação interna entre si: blasfemadores, alquimistas, libertinos, leprosos, vagabundos, sodomitas, prostitutas, ateus etc. Arquivos, diários, corpos, registros históricos, depoimentos, cartas. A atividade das pessoas estudadas por Foucault encarna uma problemática político-semântica, e é sob este prisma que analisaremos as questões filosóficas que nos interessam.

A crítica que vimos Foucault fazer às metodologias tradicionais de uma historiografia linear e contínua, nesse momento, não se pretende um novo olhar à história geral ou à fundação de uma nova instituição ou disciplina. O movimento do autor em direção a essas vidas se constitui 
em um encontro de fascínio e de admiração filosófica pelo tipo de singularidade e de narrativa que se apresenta em tais experiências. Se, em um primeiro sentido, a linguagem e a organização dos modos de vida possuem uma função de expressão que nos caberia decifrar, como uma marca velada pela superfície dos discursos, o que vemos nesses personagens são acontecimentos esquecidos e abafados. Vidas efêmeras de homens e mulheres que, em razão da obscuridade e do silêncio atribuído às suas condições bizarras de impossibilidade de conciliação entre vida e discurso, só tiveram suas existências registradas porque, em algum momento, por uma convergência de acasos, cruzaram-se com um regime de poder e criaram uma faísca em sua pretensa limpidez.

Textos concernentes a acontecimentos nos espaços de onde falam por não apresentarem uma relação isomorfa com o real e, sim, um atravessamento e uma ruptura com um determinado sistema. Tal atravessamento (termo importante para esta tese, tanto do ponto de vista conceitual, como por seu significado político) não é apenas topológico é também da ordem da subjetivação.

No contexto da consolidação de uma conjuntura do poder, onde se cruzam mecanismos políticos e efeitos de discurso que regem os discursos oficiais e mobilizam todo o desenvolvimento de uma literatura a partir deles, temos a apresentação dessas vidas abomináveis, herbário de singularidades destinadas a não figurar no discurso. Restam vãos documentos que narram suas injúrias, insultos, ciúmes, sofrimentos de toda sorte, vida e morte nos caminhos de sua fantástica "estrada desconhecida" a negar nossa possibilidade de discurso. O que se embate nesses pobres fragmentos é muito maior do que eles. $O$ fato é que tais vidas nos informam sobre nós. A palavra "Nós", neste sentido, não deve ser entendida simplesmente como um agrupamento de pessoas reunidas sob uma doutrina, tradição ou comunidade, mas também sobre nossas próprias normas, fascismos e intolerâncias.

Como vemos, Foucault apresenta uma inquietação com lugares e definições previamente estabelecidos que sobredeterminam as funções sociais. Ele busca justamente o sentimento de "sem lugar", ou melhor, a criação e proliferação de outros modos e lugares nos quais possamos falar, escutar e ser compreendidos, sem mapeamento prévio, de modo 
que o pensamento possa ser um ato perigoso e transformador, uma arma de crítica às tecnologias do poder, conforme vemos nas práticas políticas contemporâneas.

É esse "sem lugar" vislumbrado por intermédio dos personagens que Foucault apresenta. Além disso, é sua filosofia que ganha luz com as problematizações ocorridas nas vidas que se apresentam, nas acrobacias dessas outras vozes, com seus modos existenciais, fictícios, jurídicos, em movimentos intelectuais, físicos e políticos, que trazem à tona outras formas de ser. Vozes que escapam às determinações previamente organizadas e revelam uma crise, criam uma fissura em um determinado estado de coisas por meio de uma vivência individual, poética, política, filosófica, revolucionária que cria, por seu próprio acontecimento, outras formas de prazer, novas necessidades de relação, novas séries de coexistência, outros tipos de laço, de amizade, de trabalho de condução de intensidades, novos tipos de cuidado, fora das matrizes da taxonomia e da normatização moral.

Na paixão declarada do autor por esses "homens obscuros", por vidas que nos apontam questões referentes a "vidas outras", identificamos uma "dramaturgia do real", a busca por experiências nas quais se apresenta uma batalha silenciosa, uma ira, uma vingança, o registro de um outro lugar no regime da existência que nos deixa traços, ruídos, documentos, anotações a serem lidas. Vidas que nos apresentam a dramaticidade existencial de corpos e comportamentos que, por uma razão ou outra, não cabem na cartografia da normatização. Figuras que jamais se permitem evidenciar por completo, analisar de modo acabado e inequívoco. O que se apresenta nesses textos não são esquemas filosóficos. Ao invés, o que se mostra é uma inexatidão, à qual se atribui uma problematização interna da norma. Em nenhum momento pretende-se o retrato de uma determinada situação, e sim a busca por compreender tais gestos, crises, dilaceramentos impraticáveis, justificativas inaceitáveis, vidas inapropriadas, acontecimentos em função da ruptura filosófica que eles operam. Vidas que se chocam com o poder, com o discurso, com o espaço dos saberes legítimos e estabelecidos pelo homem moderno antropológico. 
Em outros escritos do autor, sobre tudo nos textos da experiência da literatura, vemos o apontamento de uma vida-outra, a vida heterotópica, a vida infame, que carrega a marca da ruptura, e Foucault nos mostra, ao longo de toda sua produção teórica e de seu posicionamento político, que há algo a ser lido nessas existências em conflito, quando a vida, o trabalho e a linguagem entram em choque com as verdades e com seus aparelhos: a produção de uma vida-outra, a qual estabelece um mundo-outro, novas formas de vida e um significado específico em um determinado contexto político. Infâmia, neste sentido, carrega tanto seu sentido literal, de não famoso, quanto seu sentido conotativo, na conotação da fama maldita, da parte maldita.

Neste contexto, se desenha uma batalha por uma história do periférico e dos desvios, que se chocam com o real e com a instituição violenta da totalidade dos axiomas metafísicos e lógico-antropocêntricos que dominam, no Ocidente, nosso pensamento sobre o limite do que somos e do que podemos ser. Uma batalha semântica e política, cujo elemento é o das próprias vidas e da representatividade desses textos no contexto de novas possibilidades de subjetividade que a obra de Foucault reivindica.

Acompanhemos o movimento da filosofia foucaultiana de uma perspectiva mais ampla. As palavras e as coisas constitui, ao mesmo tempo, de um lado, um ponto de término de um tipo de análise visada a objetividade radical do discurso para pensar as condições materiais das transformações, e de outro uma abertura para um remanejamento metodológico e conceitual. O pensamento se desloca para a relação entre os discursos e as práticas e, na sequência, no aspecto da formação e da transformações destes discursos e de suas práticas não discursivas. Nesta articulação entre discurso e poder vemos, em um terceiro movimento, a questão da subjetivação tomando corpo através da problematização ética e política da estética da existência entre o governo de si e governo do outro.

Vista a partir deste sobrevoo, compreendemos que este trabalho de pesquisa de Foucault apresentado já na Introdução ${ }^{1}$ conecta-se de

1 Em 1961, Foucault escreve uma breve Introdução à Antropologia de um ponto de vista pragmático de Kant, no qual, sabemos, está o germe filosófico de As palavras e as coisas, formando a base do trabalho do filósofo na década de 1960 e conectando-0 a autores essencialmente antissistemáticos como Nietzsche, Artaud, Bataille, Blanchot, Mallarmé etc., 
modo importante com a "analítica da finitude", conforme anunciada em As palavras e as coisas, e também com a ideia de um sentido ontológico da vida ética - para além da rede saber-poder e de suas práticas de subjetivação.

As vidas infames que Foucault apresenta são publicadas em um dossiê entre a edição de As palavras e as coisas e Vigiar e punir. Estes livros constituem dois marcos na obra do filósofo, pois apresentam uma nova concepção da história do pensamento ocidental, inscrevendo-se em uma nova perspectiva ao elaborar uma radical e original análise da relação saber-poder. A proposta de compreender a edição do dossiê, neste contexto mais geral da obra foucaultiana, faz parte de uma tentativa de compreender o próprio método do seu pensamento. $\mathrm{O}$ papel do universo periférico, o ruído que vidas indocilizáveis causam nas estruturas saber-poder e a incapacidade que a vida normatizada manifesta para com estas emergências de alteridade.

A filosofia de Foucault é um extraordinário jogo heterotópico através da história, o teatro dos corpos. A realidade não possui sentido para Foucault, senão a partir da cena dos corpos que, ao realizar os diferentes jogos de verdade, lhes mimicam, lhes caricaturam, lhes transfiguram e lhes contestam (SFORZINI, 2014).

Há uma marcada herança do movimento surrealista francês no pensamento de Foucault. Um dos lemas da época, "artistes talentueux coupez-vous les mains!" 2 , nos fala sobre um novo lugar necessário à atitude de contestação. Toda a história do pensamento que se seguiu após a Alemanha do III Reich e a França do surrealismo se depara com os horrores dos modos de pensamento universalizantes. Evidencia-se a necessidade de uma crítica à própria democracia e à legalidade que faz com que sejam conforme a lei (e úteis) os mais diferentes tipos de barbárie genocidas e exploração social e psíquica. A história, na concepção nietzsche-foucaultiana, é fábula, aleatória, concreta e criticável. Isto nos aponta algumas ideias fundamentais: que o gênio não existe. Que a arte não pode mais estar restrita a uma técnica ou habilidade

2 Leia-se, numa tradução livre: "Artistas talentosos cortem as mãos". 
específica em produção e reprodução, sem um significado outro, que aponte a uma vida-outra. O que se cria é a desconstrução do lugar do artista para uma manifestação de alteridade na vida e, como desdobramento, pensar a filosofia mesma fora de sua redoma canônica e a partir do acontecimento que altera a verdade de um tempo. Perceber o movimento crítico-filosófico fora do lugar previamente designado a ele. Percebê-lo onde vidas eventualmente se chocam com o poder e recriam, a partir deste choque, novos significados para as existências. Em A coragem da verdade Foucault fala da vida-outra como uma vida artista, como uma vida que toma forma em rupturas e aciona os movimentos da arte moderna e dos revolucionários, que criam para si existências críticas e singulares que não podem ser reduzidas às dimensões das normas ordinárias.

Práxis não é simplesmente prática entendida como um processo técnico qualquer. É uma relação entre teoria e prática da maior radicalidade, que se apresenta na vida, e se constitui politicamente como uma ação estético-política que questiona a própria ideia de pessoa, bios. Estética, no contexto que aqui se apresenta, refere-se a uma experiência no mundo que seja de deslocamento, pelas perspectivas dos deslocamentos, dos riscos implicados e dos prazeres de uma existência que afirme para si a possibilidade de uma vida-outra, rompendo com os humanismos de forma marginal desejável e criadora.

As reverberações do trabalho de Foucault no debate do chamado pós-humanismo orbitam justamente em torno de uma possibilidade de variabilidade de identidade política como modo de evitar essencialismos de qualquer sorte, como possibilidade de recusa de universalismos e transcendentalismos subjacentes às hierarquias de categorias como raça, classe, orientação sexual, etnicidade, religião, as identidades que fundam um nós e um outro.

Em um texto de 1971, Foucault articula o ponto de vista que será o elo entre a crítica ao humanismo e às filosofias da consciência, descrito nos anos 1968-69, e a crítica à ideia de soberania, explicitada em 1976. 
[...] eu entendo por humanismo o conjunto de discursos pelos quais nós dizemos ao homem ocidental: "mesmo quando você não exerce o poder, você pode igualmente ser soberano. Ou melhor: quanto mais você renunciar a exercer o poder, melhor você será submisso ao que lhe é imposto, mais você será soberano". O humanismo foi o que inventou ponto a ponto as soberanias assujeitadas que constituem a alma (soberania sobre o corpo submisso a Deus), a consciência (soberania na ordem do julgamento submisso a verdade), o indivíduo (soberano possuído de seus direitos, submisso às leis da natureza e às regras da sociedade), a liberdade fundamental (interiormente soberano, exteriormente ajustado e concordado a seu destino). Isto é, o humanismo é tudo aquilo através do que, no Ocidente, nos barramos o desejo de poder - interdito de desejar o poder, excluído da possibilidade de toma-lo para si. No centro do humanismo, a teoria do sujeito, no duplo sentido da palavra (FOUCAULT, 2001b).

Existe um problema na obra de Foucault, que ele apresenta em $A s$ palavras e as coisas, conforme anuncia as figuras fundamentais do saber moderno que possuem, como pano de fundo, sua própria ruptura como condição constituinte. Uma vez que toda a base do trabalho da década de 1960, o conecta a autores essencialmente antissistemáticos como Nietzsche, Artaud, Bataille, Blanchot, Mallarmé etc., indica-se o tipo desertor de interesse e de abordagem que Foucault pretende com a questão do sujeito.

Talvez este posicionamento possa iluminar o sentido de pós-humano presente no pensamento contemporâneo, e que já se anunciava desde o prefácio à Antropologia escrito por Foucault, no princípio de seu pensamento filosófico: o de uma crítica a um sujeito coerente e estável que regule e retifique suas relações como um pré-requisito metodológico e normativo à sua qualificação como sujeito jurídico.

A historicidade, que criou um homem definido pelas marcas do pensamento científico e moderno, é decorrente da passagem da epistême clássica para a moderna e se dá no seio de um pensamento radical sobre a linguagem e o papel desempenhado por ela na produção das realidades e do que hoje entendemos por "ciências humanas". A filosofia crítica de Kant instituiu o corte epistemológico que funda a modernidade como fato discursivo, entre os séculos XVIII e XIX. 
A ruptura que vemos em As palavras e as coisas é a transfiguração do sentido da experiência cartesiana do "penso, logo existo", que permitia ao "eu" suspender a dúvida sobre sua existência pela experiência de seu próprio pensamento, e garantia a correspondência entre pensamento e realidade. Isto significa que a própria existência (do real e do sujeito) passa a apresentar-se a partir do campo da linguagem e do pensamento, e não de uma suposta origem ${ }^{3}$ que existiria previamente ao sentido que lhe é atribuído. O papel do homem é questionado no processo de significação e, nesta medida, quando se faz objeto de seu próprio estudo, reduplica-se nas ciências humanas, mas faz isso a partir de uma ignorância originária, em sua própria ausência.

Os constrangimentos das vidas e das situações políticas do poder começam já nos quadros normativos da história e da genealogia das forças que eles produzem para se afirmar como maquinaria. A ideia de sujeito, assim como a suposição de um "antes" temporal que ele evoca, constitui-se pela lei, como um fundamento fictício que seria a própria reivindicação de sua legitimidade. Tal suposição, que garantiria uma integridade ontológica ao sujeito, o conformaria perante a lei. Esta articulação pode ser compreendida como um vestígio contemporâneo da hipótese do estado natural, nossa "fábula fundadora, que é constitutiva das estruturas jurídicas do liberalismo clássico" (BUTLER, 2015). Essa suposta condição não histórica garantiria um fundamento para uma ontologia pré-social de pessoas que consentem livremente em serem governadas, legitimando, assim, um contrato social. Ora, a própria ideia de um sujeito pré-social, como sabemos, desde Nietzsche, Marx e Freud, não pode mais ser exaustiva ou resoluta. Não é mais possível separar a noção de sujeito das interseções políticas e culturais nas quais ela é produzida e mantida.

A ideia de sujeito, a identificação humana política e social que o ser homem criou pra si e para os outros no ocidente. Obviamente, a tarefa

3 Como já vimos, tal ideia não passa de uma miragem no pensamento de Foucault. "0 genealogista precisa da história para conjurar a quimera da origem, um pouco como o bom filósofo necessita do médico para conjurar a sombra da alma" (FOUCAULT, 2001b). 
política não é recusar a política representacional - como se pudéssemos fazê-lo. As estruturas jurídicas da linguagem e da política constituem o campo contemporâneo do poder; consequentemente, não há posição fora desse campo, mas somente uma genealogia crítica de suas próprias práticas de legitimação. Assim, o ponto de partida é o presente histórico, como definiu Marx. E a tarefa é justamente formular, no interior dessa estrutura constituída, uma crítica às categorias de identidade que as estruturas jurídicas contemporâneas engendram, naturalizam e imobilizam (BUTLER, 2015).

Foucault trabalha a partir da possibilidade de abertura para "vidas outras", em uma crítica política a uma organização social, cientificista, racional e burocrática da economia da medida na vida humana. O que interessa ao filósofo são as consequências políticas desse tipo de produção de tecnologias em lógica de troca, aplicada às vidas humanas, num pensamento a partir do que a excede, de seu dispêndio no incapturável. Em todo seu trabalho, impera o gesto do corte, das partilhas, das figuras, das configurações, dos estratos, das séries, das estratégias. As implicações de sua arqueologia partem do corte radical no solo de nossas experiências que constituíram um homem fechado em sua racionalidade, abrindo caminho para a emergência de outras configurações, outras possibilidades e formas a esse mesmo pensamento ocidental. Um homem que devenha distinto de si mesmo, em novos efeitos de significado, um homem desorganizado, desfeito, que opere um desmembramento do homem inventado pelo pensamento antropológico e pelas entranhas da rede do poder-saber que nos formam como sujeitos produtivos.

\section{Vidas-outras}

A ideia de vida-outra aparece no pensamento de Foucault no seu último curso no College de France - A coragem da verdade - em 1984, fazendo referência a um modo de existência que problematiza a moralidade de seu tempo criando um embate político, uma postura ética, 
um risco na relação com si mesmo e com os outros. Neste curso o autor traz a figura de Diógenes como grande exemplar, que com sua "crítica gestual" levava ao extremo uma nova significação da prática dos afrodisia e da askesis, na qual a parresía adquire uma importância central, de tal modo que a vida cínica se constitua inteiramente como um exercício permanente.

O trabalho ético que vemos em Foucault na década de oitenta, referindo-se a um questionamento sobre as possibilidades do sujeito em sua relação com o mundo, pode ser lido em uma recolocação do problema do sujeito tal qual se coloca nos textos que dialogavam com a "analítica da finitude", como descrita em As palavras e as coisas já no início da obra foucaultiana - principalmente nos textos sobre literatura e no prefácio à Antropologia kantiana.

Ainda que Foucault não tenha propriamente traçado os contornos deste personagem, talvez, curiosamente, ele é o que mais "realmente" se constitui como tal. A função de anúncio que a paródia das formas literárias e teatrais - especialmente a tragédia - desempenha na difusão das ideias da escola cínica é central e muito mais forte do que os registros escritos.

Primeiramente, devemos levar em consideração a forte marca cínica da dramaturgia e teatralidade. Diógenes é mais, propriamente, um personagem na história da filosofia do que um filósofo, um escritor, um caso clínico-jurídico, um caso médico-legal. Se existe alguma linguagem que podemos dizer cínica é a teatral, tanto cômica quanto trágica. O fato de o cínico ter escolhido a tragédia como modo de abordar as questões políticas não pode ser compreendido fora desta tensão interna da própria filosofia, entre discurso filosófico e literatura. A polêmica da figura de Diógenes já parte, portanto, de um posicionamento político, pois, enquanto as escolas filosóficas de seu tempo estavam começando a situar a tradição da literatura como benefício ao intelecto, fazendo-a assimilável às instituições e modelos de comunidade política, com lugar e função demarcados, Diógenes recorre a ela para, ainda que em sua específica dimensão teatral, performativa, destruir a cidade. Diógenes de Sinópe transforma os dramas de sua existência na 
pólis em conduções doutrinais satíricas nas quais ele expõe suas proposições ético-político escandalosas.

Existia uma marca definida no estranho tipo de homem que aqui apresentamos. Aspecto ordinário, trapos com os quais se aquece no inverno, barbas e cabelos longos, vara, sacola, pés descalços. Eles acreditavam que somente a prática do máximo desprendimento, independência, errância, hostilidade, poderia levá-los ao nível de descompromisso moral que sua tarefa exigia.

Diógenes exercitava, em praça pública, um tipo de cinismo que era mais uma prática do que uma doutrina. Segundo relatos, ele se afastava das ciências da cidade e se aproximava das artes aprazíveis, em aptidões e modos de vida extravagantes, por meio da execução de determinados exercícios, para atingir um determinado estado almejado. Artes da existência que podem ser adquiridas se praticadas como ascese, como um desenvolvimento de técnicas sobre si por meio de exercícios corporais, assim como vemos fazer os atletas e os músicos. Tal cinismo pretende construir uma confiança em um vigor através desses exercícios que, na elaboração do respectivo modo de vida, estabelecem a acentuação que cada homem deve problematizar, na própria experiência, como escândalo da verdade. Um movimento que critica os principais valores da cidade e os modos de vida comumente almejáveis como origem de vício, e não de soberania.

Para o trabalho sob o aspecto ético que apresentamos, uma outra ideia importante da filosofia cínica representada por Diógenes é a de autarquia, na qual Foucault recupera como um elemento central e um conceito motor do seu pensamento, um esforço para recriar-se de acordo com novos critérios, de dar uma forma ética à própria vida na estética da existência. A autarquia consiste basicamente em uma liberação progressiva das necessidades, hábitos e vícios com os quais os homens se acostumam na vida moral. Tal liberação faz com que o homem baste a si mesmo e este deve ser o ideal do sábio. Uma vez que a maior parte das necessidades dos homens morais procede de hábitos, costumes e tabus da pólis, ao cínico se coloca a tarefa de romper com os códigos prescritos. Não cultuavam alianças políticas de nenhum tipo. De fato, se tivermos em mente que tais homens se diziam cidadãos do mundo, 
as leis que eles se proclamam devem ser leis da virtude, e não dos costumes restritos a cidade e a vida moral individual de cada cidadão. $\mathrm{O}$ cínico toma para si como ponto de partida um comprometimento com um tipo de vida não dissimulada, não misturada, firme e estável, causando um estremecimento no conceito de vida verdadeira. $\mathrm{O}$ cinismo era muito mais um modo de vida do que propriamente uma doutrina filosófica. Essa posição, especificada no mote ético de "mudar o valor da moeda"4 , funciona como uma fala que encarna a transmutação dos valores, na qual o homem se autoemancipa dos prejuízos ordinários, em virtude de sua independência, sua autarquia, sua incorruptibilidade atlética. É uma vida que faz aparecer, indo ao seu próprio extremo e situação limite, temas de questionamento que só podem ser postos por uma pessoa que esteja tratando a vida a partir de outro valor. Por isto não poderíamos esperar que o pensamento cínico chegasse a nós do mesmo modo que recebemos as documentações filosóficas de uma determinada comunidade cultivada. O que se apresenta no cinismo é uma filosofia de ruptura e de contestação, desestabilizando o centro da cidade e seus valores.

Talvez seja em razão do desprezo às instituições da pólis e aos traços escandalosos de sua vida, que os escritos de Diógenes tenham sido relegados ao esquecimento e ao obscurantismo pela história do pensamento e das moralidades. Parece que ele escreveu Politeia ( $A$ República), que depois foi retomada por Zénon de Cition, e que, primordialmente, atacava os valores vigentes no mundo grego, afirmando outros, como liberdade sexual total, indiferença ao sepultamento, igualdade entre homens e mulheres, negação de qualquer sagrado, desprezo por convenções sociais, supressão das armas e do dinheiro, proposta de autossuficiência a fim de alcançar uma liberdade material e mental - um materialismo que se vincula à individualidade do real conforme nega as ideias abstratas que fundamentariam a existência. Apresenta-se uma filosofia que consiste na incorporação de uma vida fora da norma, que escandaliza uma determinada sociedade e que

4 Mudar o valor da moeda, parakharattein to nomisma carrega a polissemia da palavra nomos: 'lei,', valor' e'palavra' conforme estes sentidos operavam no mundo grego. 
- neste ponto, especialmente para Foucault - possui uma concepção de virtude como fim em um ativismo político que se pratica na própria vida, não na ciência. Um ativismo que apresenta um modo de vida o qual não quer precisar de nada além de coragem e retidão de espírito.

Pouco após a morte de Sócrates, no século IV a.C., Platão apresenta o Teeteto como uma entrevista-homenagem ao mestre, na qual ele nos diz que uma vida dedicada ao pensamento, a uma vida intelectual, é impossível, a não ser que se estabeleça um sistema de ideias distintas e hierarquicamente relacionadas.

Platão, como sabemos, passa grande parte de seus diálogos tentando definir e compreender a relação entre as ideias em seus diferentes níveis ontológicos, de modo a distingui-las e organizá-las em função do Bem supremo. Toda a sua doutrina, conforme podemos ver em breves sentenças de Diógenes, é antípoda daquela de seu mestre.

Um traço que conecta o pensamento cínico com o socrático, e que remonta à sofística, na realidade, é a forte presença da ideia de um engajamento na educação como meio de formação e de transformação dos homens, de acordo com métodos e práticas racionais. Educação encarnada, evidentemente. Os cínicos se apresentavam aos homens como bússolas, como pessoas que, com a própria vida, indicavam caminhos e valores. Caminhos e valores a partir de uma postura de crítica e de ruptura radical com os modos de vida vigentes. É o poder sobre si, o cuidado de si, que vai regular o poder sobre os outros e o poder dos outros sobre si. A ascese que acontece neste jogo é por uma vida atenta, cuidadosa e corajosa, para além da parresía, como estratégia na própria existência, com tudo que ela implica.

Ainda, ele traz um outro tipo de experiência que possui traços característicos análogos, outros movimentos culturais que nos apresentam heranças da filosofia do cinismo antigo no choque com a vida política moderna. Ele nos apresenta movimentos artísticos e culturais que tomam para si a função de manifestação da verdade na crise em proveito de uma vida-outra. 


\section{Considerações finais}

Vemos que Foucault faz crítica de arte com existências. Existe uma busca onto-arqueológica por uma estética do moralmente abjeto, cuja beleza de sua expressão está em sua problematização moral, seja ela performática, orgânica, fabulosa, trágica, ignóbil, impossível, filosófica. Uma beleza que se cria conforme a autoridade que esta vida-outra agride.

O contexto no qual ele apresenta este trabalho tem como uma das ideias centrais a noção grega de cuidado-de-si. Noção ampla e variada mas que pode ser indicada como um eixo ético nas pesquisas foucaultianas pelas tecnologias morais e subjetivas pelas quais pessoas conduzem vidas e mortes, de si e dos outros.

O trabalho ético de Foucault, bem como a ideia de vida-outra, não mira um retorno ao mundo grego; o que o filósofo não cessa de fazer é identificar quebras em sistemas de atualidade. Esta possibilidade de composição aqui feita, em momentos tão distintos da obra do autor, é garantida pela elaboração de análise das diferenças entre os regimes epistemológicos próprios às diferentes épocas de saber, em cada à prio$r i$ histórico que as constitui. O estudo das técnicas de si gregas funcionam na obra de Foucault como mais um instrumento para a criação de problematizações morais, sempre e necessariamente contemporâneas a seu regime de saber e de poder, de vida e de morte.

\section{Referências}

FOUCAULT, M. Dits et ecrits I. 1954-1975. Paris: Gallimard, 2001a.

FOUCAULT, M. Dits et ecrits II. 1976-1988. Paris: Gallimard, 2001b.

FOUCAULT, M. As palavras e as coisas: uma arqueologia das ciências humanas. Trad. Salma Tannus Muchail. 9. ed. São Paulo: Martins Fontes, 2007.

FOUCAULT, M. Le Courage de la a Vérité - Cours au collège de France. 1984. Paris: Gallimard, 2009. 
BUTLER, J. Problemas de Gênero. Feminismo e subversão da identidade. Trad. Renato Aguiar. Rio de Janeiro: Civilização Brasileira, 2015.

SFORZINI, A. Michel Foucault. Une pensée du corps. Paris: PUF, 2014.

Recebido: 20/08/2016

Received: 08/20/2016

Aprovado: $18 / 10 / 2016$

Approved: 10/18/2016 